\title{
Temporary Augmentation of Paradoxical Sleep and Slow Wave Sleep by Inhibitors of RNA Synthesis
}

\author{
Eiko UezU* and Junji Matsumoto \\ Department of Physiology, School of Medicine, The University of Tokushima, \\ Tokushima, 770 Japan
}

\begin{abstract}
Summary Intraventricular administration of actinomycin D and actinomycin $S_{3}$, inhibitors of RNA synthesis, did not suppress paradoxical sleep (PS), but actinomycin $\mathrm{S}_{3}$ increased PS and deep slow wave sleep (DS) in the dark period (18:00-06:00), suggesting that RNA synthesis plays a role in the decrease of DS and PS in the dark period of circadian rhythm.
\end{abstract}

Key Words: actinomycin $\mathrm{D}$, actinomycin $\mathrm{S}_{3}$, sleep.

In previous reports, it was shown that inhibitors of protein synthesis suppress the appearance of paradoxical sleep (PS) (MATSUмото et al., 1979; UeZU et al., 1981). Similar results have been reported from several other laboratories (Pegram et al., 1973; Kitahama and Valatx, 1975; Rojas-Ramirez et al., 1977). However, the questions of which proteins are affected, or whether specific proteins for PS appearance exist in the brain and how their synthesis or catabolism may occur have not been answered. In the present study, inhibitors of RNA synthesis were given to rats to further investigate the route of protein synthesis.

Male Wistar rats weighing 250-300 g were used in the experiments. A cannula was implanted into the right lateral ventricle of the brain as previously described (UEzU et al., 1981). Screw electrodes were placed on the frontal and occipital cortices for long-term electroencephalogram (EEG) recording. Stainless-steel wire electrodes were used for recording the electrooculogram (EOG), electrocardiogram (EKG), and electromyogram (EMG) of the neck muscle. After the operation, the animals were individually housed in an observation chamber with a $12 \mathrm{hr}$ lightdark cycle (light: 06:00-18:00), and fed Oriental M. F. (24\% protein), a solid food from Oriental Yeast Co., Ltd. (Tokyo). Food and water were freely available. One week after recovery from surgery, continuous polygraph recordings of the EEG, EOG, EKG, and respiratory activity of the animals were taken for $48 \mathrm{hr}$.

\footnotetext{
Received for publication March 12, 1982

上汇洲栄子, 松本淳治

* Present address: Department of Physiology, Okayama University Medical School, Okayama, 700 Japan
} 


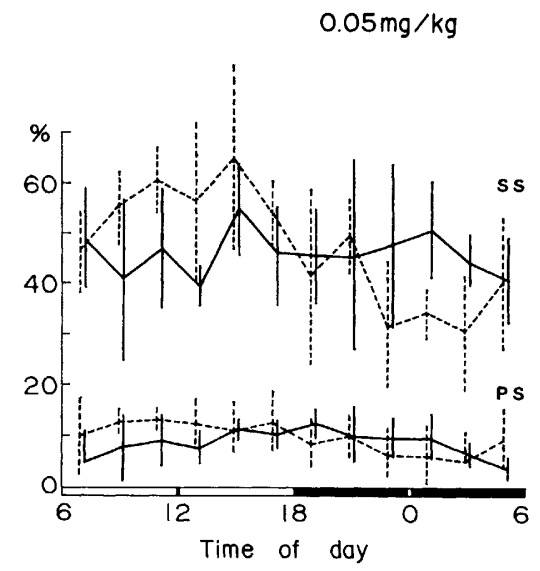

A
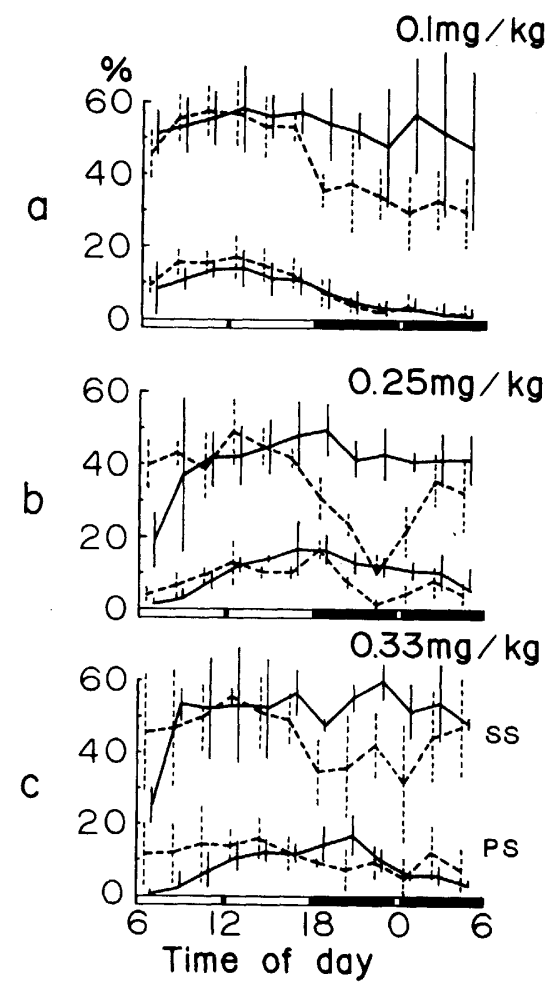

B

Fig. 1. A: effects of an intraventricular injection of $\mathrm{AcD}(0.05 \mathrm{mg} / \mathrm{kg}$ in a volume of 0.25 $\mathrm{ml} / \mathrm{kg}$ ) on the amount of SS and PS. Points represent the mean per cent \pm s.d. (5 rats) of SS and PS respectively at $2 \mathrm{hr}$ period. - --, baseline; - _, AcD. B: effects of an intraventricular injection of $\mathrm{AcS}_{3}$ on the amount of SS and PS. Groups of 4 rats were given 0.1 (a) and $0.25 \mathrm{mg} / \mathrm{kg}$ (b) of $\mathrm{AcS}_{3}$. Three rats were given $0.33 \mathrm{mg} / \mathrm{kg}$ (c). Points indicate the mean per cent \pm s.d. of SS and PS respectively at each $2 \mathrm{hr}$ period. - - , baseline; -, $\mathrm{AcS}_{3}$.

Actinomycin D (AcD) and actinomycin $\mathrm{S}_{3}\left(\mathrm{AcS}_{3}\right)$, inhibitors of RNA synthesis, were purchased from Sigma Chemical Co. and Calbiochem. Following a $24 \mathrm{hr}$ baseline recording, one of the inhibitors dissolved in physiological saline solution, was slowly injected over a $2 \mathrm{~min}$ time period at a volume of $0.25 \mathrm{ml} / \mathrm{kg}$ through the cannula at 06:00. Changes in the sleep pattern induced by the drugs were investigated in comparison with the baseline recording. From the polygraph patterns, three states were defined as awake, slow wave sleep (SS) and PS according to the classification of MATSUMOTо et al. (1967). SS was divided into light sleep (LS) and deep sleep (DS) depending on the polygraph patterns such that LS was defined as the state in which the EEG was 100-200 $\mu \mathrm{V}$ and 2-8 cps with regular respiration and DS as the state in which the EEG was $200-400 \mu \mathrm{V}$ and $1-13 \mathrm{cps}$ 
Table 1. Effects of $\mathrm{AcS}_{3}(0.25 \mathrm{mg} / \mathrm{kg})$ on LS, DS, and PS in light and dark.

\begin{tabular}{llccc}
\hline & & \multicolumn{1}{c}{ LS } & \multicolumn{1}{c}{ DS } & PS \\
\hline Light period & Baseline & $12.33 \pm 0.82$ & $30.98 \pm 1.24$ & $8.98 \pm 0.96$ \\
(06:00-18:00) & Experiment & $10.45 \pm 5.00$ & $28.18 \pm 4.08$ & $8.98 \pm 1.14$ \\
Dark period & Baseline & $7.20 \pm 0.33$ & $18.55 \pm 2.40$ & $6.73 \pm 2.99$ \\
$(18: 00-06: 00)$ & Experiment & $9.68 \pm 3.88$ & $32.70 \pm 6.02^{*}$ & $11.08 \pm 2.99^{*}$ \\
\hline
\end{tabular}

Values indicate the per cent \pm s.d. of the $12 \mathrm{hr}$ recording time. ${ }^{*} p<0.05$, muchedpaired $t$-test (comparison with the baseline).

with regular respiration.

AcD given intraventricularly at $0.05 \mathrm{mg} / \mathrm{kg}$ at $06: 00$ did not cause an abnormal EEG pattern. Compared with the baseline, SS decreased during the light period and increased later in the dark period as shown in Fig. 1A. PS also showed the same trend. Figure 1B shows the effect of $\mathrm{AcS}_{3}(0.1,0.25$, and $0.33 \mathrm{mg} / \mathrm{kg}$ ) on SS and PS. The three doses of $\mathrm{AcS}_{3}$ blocked the decrease of SS ordinarily seen in the dark period, without suppressing it in the early light period. Considering the LS and DS components of SS at the dose of $0.25 \mathrm{mg} / \mathrm{kg}$, DS showed a clear circadian rhythm as reported previously (UEzU et al., 1981), was unaffected in the light period and significantly increased in the dark period as indicated in Table 1. LS was unaffected in both periods. DS can be considered to be a principal element of the SS circadian rhythm which may be affected by $\mathrm{AcS}_{3}$.

The effect of $\mathrm{AcS}_{3}$ on PS was different depending upon the dose given, but no linear relationship between the effect and the dose was observed. $\mathrm{AcS}_{3}$ at $0.1 \mathrm{mg} / \mathrm{kg}$ slightly suppressed PS the day after administration. $\mathrm{AcS}_{3}$ at $0.33 \mathrm{mg} / \mathrm{kg}$ suppressed PS for $6 \mathrm{hr}$ after the administration, but the amount of PS increased steadily thereafter and exceeded the baseline level from 18:00 to 00:00. At a dose of $0.25 \mathrm{mg} / \mathrm{kg}$, PS increased following a slight suppression in the early period after administration. An increase of PS for $24 \mathrm{hr}$ was observed in all subjects given $\mathrm{AcS}_{3}$ at $0.25 \mathrm{mg} / \mathrm{kg}$; however the increase was not significant. In the dark period, the increase of PS was significant when compared with baseline level as shown in Table 1. But PS disappeared in all animals $28-34 \mathrm{hr}$ after the administration of AcD or $\mathrm{AcS}_{3}$.

The RNA synthesis inhibitors were so toxic that all animals died within 3-4 days. Inferences regarding the physiology of sleep derived from such sick animals may be somewhat questionable. However during the $24 \mathrm{hr}$ period following administration of the inhibitors, the animals had normal EEG patterns and other physiological parameters used in the judgement of whether awake or asleep were also normal. Typical PS, which is accompanied by desynchronization of the cortical EEG, rapid eye movement, disappearance of EMG and irregular respiration, was also seen in the treated animals. General behavior and feeding activity were normal as well. Furthermore, AcD showed no effects on the acquisition of learning at the very high doses (Mishima and Hashimoto, 1977). Thus it was 
thought that the animals had qualitatively normal waking and sleeping at least up to $24 \mathrm{hr}$ after the administration of the RNA synthesis inhibitors, though they had some quantitative changes in their sleep patterns.

Toxicity of $\mathrm{AcD}$ and $\mathrm{AcS}_{3}$ may be due to their irreversible effects on RNA synthesis. It is noteworthy that in spite of such irreversible effects, with administration of the agents, no significant decrease in the amount of PS for $24 \mathrm{hr}$ is observed. This fact indicates that newly synthesized RNA is not needed for the appearance of PS for $24 \mathrm{hr}$. The suppression of PS induced by inhibitors of protein synthesis (UEZU et al., 1981) but not by inhibitors of RNA synthesis even in fatal doses, suggests that the occurrence of PS requires specific protein associated with longlived messenger RNA (mRNA) which is unaffected by inhibitors of RNA synthesis for at least $24 \mathrm{hr}$. We have also observed that $\alpha$-amanitin, a specific inhibitor of mRNA synthesis, did not cause notable change in the amount of PS. The increase of PS in the group administered $\mathrm{AcS}_{3}$ at a dose of $0.25 \mathrm{mg} / \mathrm{kg}$ may be caused by the effect of $\mathrm{AcS}_{3}$ in blocking the normal decrease of PS in the dark period. As mentioned previously, major reports indicate that PS is inhibited by agents that block protein synthesis, and there is the view that protein synthesis triggers PS. From the above results, it seems that RNA synthesis is concerned with the circadian rhythm of PS rather than the triggering mechanism.

In the case of SS, on the other hand, AcD suppresses it in the light period. However, it is difficult to decide if this effect of $\mathrm{AcD}$ on SS is due to inhibition of RNA synthesis because AcD caused an abnormal EEG at a higher dose (MATSUмото et al., 1978). $\quad \mathrm{AcS}_{3}$, which showed no effect on the EEG, did not suppress SS in the same period. The increase of SS in the dark period was common to all animals given either AcD or $\mathrm{AcS}_{3}$. It seems that inhibition of RNA synthesis suppresses the decrease of SS, especially DS, in the dark period; thus, newly synthesized RNA may play a role in the decrease of DS in the dark which is part of the normal circadian rhythm. RNA synthesis may be related to the normal decrease of SS and PS of rats in the dark period.

It is well known that inhibitors of macromolecule synthesis sometimes show a "paradoxical effect" or "superinduction" on some proteins (GARREN et al., 1964; Reel et al., 1970; Tomkins et al., 1972; Palmiter and SchimKe, 1973). Such effects of these inhibitors may offer an explanation for the increase of DS or PS in treated animals. Further study of the sleep mechanism in relation to RNA synthesis will require more detailed information about "superinduction."

\section{REFERENCES}

Garren, L. D., Howell, R. R., Tomkins, G. M., and Crocco, R. M. (1964) A paradoxical effect of actinomycin D: The mechanism of regulation of enzyme synthesis by hydrocortisone. Proc. Natl. Acad. Sci. U. S. A., 52: 1121-1129.

Kitahama, K. and ValatX, J. L. (1975) Effects du chloramphenicol et du thiamphenicol sur le someil du la souris. C. R. Séances Soc. Biol., 169: 1522-1525. 
Matsumoto, J., Morita, Y., Sano, A., Ishikawa, N., Seno, H., and Uezu, E. (1978) Nervous and humoral factors in sleep mechanisms. In: Integrative Control Functions of the Brain, Vol. 1, ed. by Iто, M. et al. Elsevier, Amsterdam/Kodansha, Tokyo, pp. 400-401.

Matsumoto, J., Nishisho, T., Suto, T., Sadahiro, T., and MiYoshi, M. (1967) Normal sleep cycle of male albino rats. Proc. Jpn. Acad., 43: 62-64.

Matsumoto, J., Uezu, E., and SANo, A. (1979) Effects of inhibitors of protein synthesis on paradoxical sleep in rats. In: Integrative Control Functions of the Brain, Vol. 2, ed. by Iтo, M. et al. Elsevier, Amsterdam/Kodansha, Tokyo, pp. 364-366.

Mishima, N. and HASHIMOTO, T. (1977) Impairment of acquisition of learning by inhibitors of RNA or protein synthesis. Jpn. J. Physiol., 27: 267-277.

PALMITER, R. D. and SCHIMKe, R. T. (1973) Regulation of protein synthesis in chick oviduct. J. Biol. Chem., 248: 1502-1512.

Pegram, V., Hammond, D., and Bridgers, W. (1973) The effects of protein synthesis inhibition on sleep in mice. Behav. Biol., 9: 377-382.

ReEL, J. R., LeE, K. L., and KeNNEY, F. T. (1970) Regulation of tyrosine $\alpha$-ketoglutarate transaminase in rat liver. J. Biol. Chem., 245: 5800-5805.

Rojas-Ramirez, J. A., Aguilar-Jimenez, E., Posadas-Andrews, A., Bernal-Pedraza, J. G., and DRUCKER-Colin, R. R. (1977) The effects of various protein synthesis inhibitors on the sleep-wake cycle of rats. Psychopharmacology, 53: 147-150.

Tomkins, G. M., Levinson, B. B., BaXter, J. D., and Dethlefsen, L. (1972) Further evidence for posttranscriptional control of inducible tyrosine aminotransferase synthesis in cultured hepatoma cells. Nature (New Biol.), 239: 9-14.

Uezu, E., SANo, A., and Matsumoto, J. (1981) Effects of inhibitors of protein synthesis on sleep in rats. Tokushima J. Exp. Med., 28: 9-16. 